J. Dairy Sci. 96:2727-2727

http://dx.doi.org/10.3168/jds.2013-96-4-2727

(C) American Dairy Science Association ${ }^{\circledR}, 2013$.

\title{
Erratum to "Short communication: Analysis of health and survival in a population of Ontario Holstein heifer calves" (J. Dairy Sci. 96:1800-1885)
}

\section{E. McCorquodale, A. Sewalem, F. Miglior, D. Kelton, A. Robinson, A. Koeck, and K. E. Leslie}

Figure 1 (page 1883) contained 2 identical panels (b and c). The corrected figure is shown below, including the correct data for panel $b$.

The authors regret the error.

\section{REFERENCES}

McCorquodale, C. E., A. Sewalem, F. Miglior, D. Kelton, A. Robinson, A. Koeck, and K. E. Leslie. 2013. Short communication: Analysis of health and survival in a population of Ontario Holstein heifer calves. J. Dairy Sci. 96(3):1800-1885. http://dx.doi. org/10.3168/jds.2012-5735.

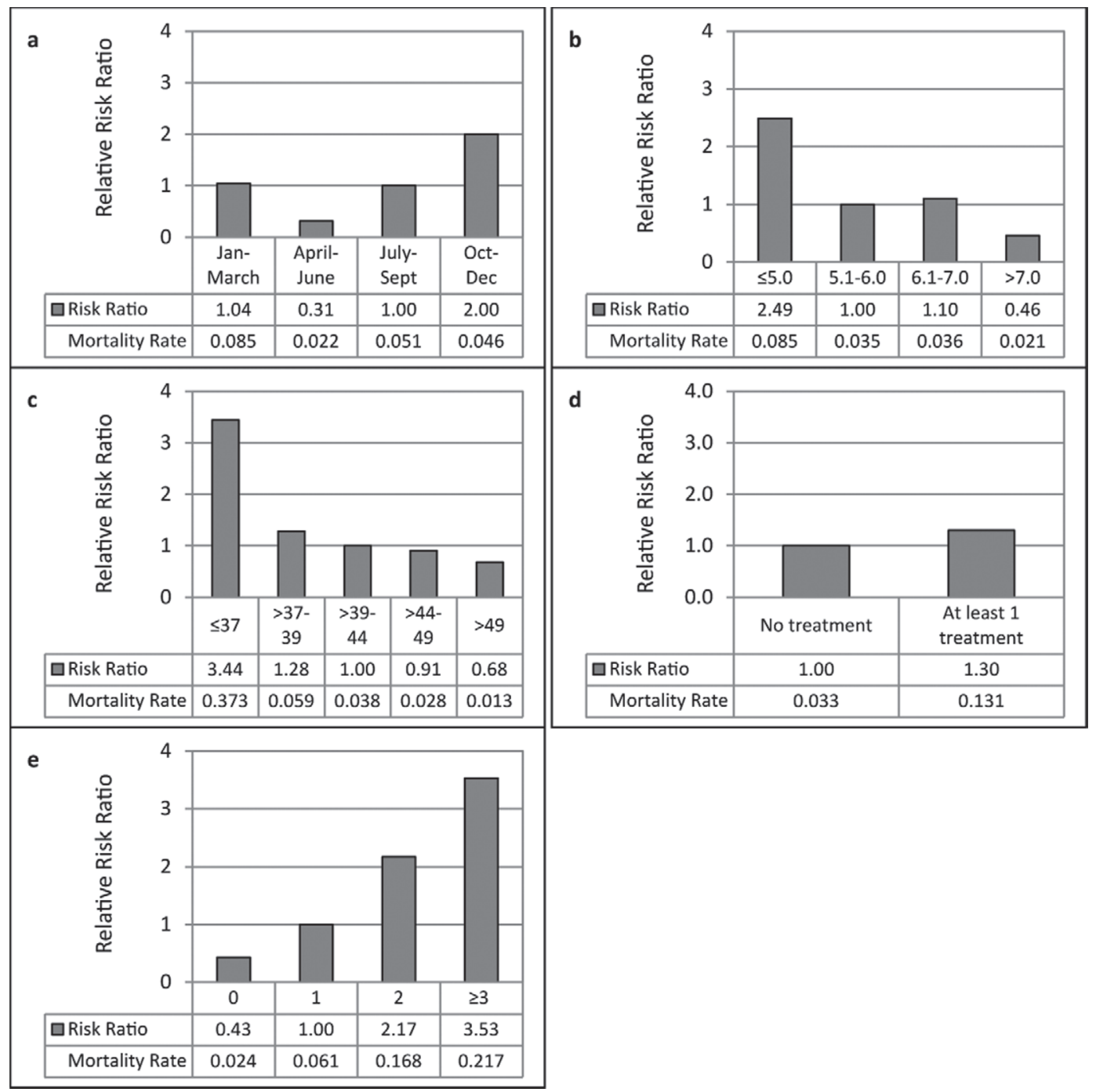

Figure 1. Relative risk ratios of mortality for (a) season of birth; calves born between July and September was set to 1; (b) serum total protein $(\mathrm{g} / \mathrm{dL})$; protein group between 5.1 and 6.0 was set to 1 ; (c) weight at 0 to $8 \mathrm{~d}$ of age $(\mathrm{kg})$; weight group between 39 and 44 was set to 1 ; (d) treated during first week of age; and (e) number of treatments; calves receiving 1 treatment was set to 1 as a reference group. 